\title{
Life Skill Training among Young People: A Pan Commonwealth Perspective
}

\author{
Praveen Varghese Thomas", M. S. W., Sonny Jose \\ Loyola College of Social Sciences, University of Kerala, India
}

\begin{abstract}
Young people constitute the majority of population in Asia and Africa region now and will remain, the same for few more decades. Young people are identified as the reagent of development across the globe. In fact, the Sustainable Development Goals, which has been proclaimed recently by the United Nations -which is a follow-up global agenda to the Millennium Development Goals also emphasizes the importance of young people in the course of sustainable development. Life skill training has become an invincible ingredient of discussions; particularly while the discussing about development in line with young people. The recent discussions by all international bodies have significantly gladdened the topic and mounted country specific policies and programmes allied to the same. Countries like India, Sri Lanka, Singapore and Malaysia has already started to capitalize young people and impart life skill training for them. The enormous amount invested on young people is been equalized to the future of the country. The current paper investigates on the possibility and strategies to slot in the life skill training in Asian countries to equip the young people to ensure their productive contribution to the economy. It further describes different approaches to the life skill training across globe and the success identified. The study is purely on the basis of the secondary data available with the Commonwealth Secretariat and other international bodies.
\end{abstract}

Keywords Life Skill, Training, Young People, Commonwealth, Sustainable Development

\section{Introduction}

....courage to think differently, courage to invent, to travel the unexplored path, courage to discover the impossible and to conquer the problems and succeed. These are great qualities that they must work towards.... - A P J Abdul Kalam

UN Secretary General Ban Ki-moon seems very keen in conceding young people's role in the world economy and sustainable development. It is in this context he has stood up for young people's effective participation and quoted as follows; "Let us acknowledge and celebrate what youth can do to build a safer, more just world. Let us strengthen our efforts to include young people in policies, programmes and decision-making processes that benefit their futures and ours." But then how?

Young people are often tagged as beneficiaries and target groups, in fact it's high time to go beyond it and consider them as contributors and thereby change makers. This is the decade where the world has the largest generation of youth ever known, and the vast majority of whom live in developing countries - has unprecedented potential to advance the well-being of the entire human family. Yet majority young people, including those who are highly educated, suffer from low-wage, dead-end work and record levels of unemployment. Following them, another section of young people has no immediate prospects and is marginalized from the political, social and development processes in their respective countries. Such actions are indirectly creating risk of having "lost generation" of misspent talent and dreams.

These days most of the international forums, International organizations and on Governmental organizations has prioritized youth as their working target. Working with and for young people has been a hot topic of the decade. As per Ban Ki-moon: "Youth are a transformative force; they are creative, resourceful and enthusiastic agents of change, be it in public squares or cyberspace"

According to a new United Nations report (2014) the swell in the global population of young people has the potential to transform economies for better or worse, depending on the decisions of today's policy makers,

UN Population Fund (2014, November) estimates that the global population of young people between the ages of 10 and 24 has hits 1.8 billion, a historic high. "Never again is there likely to be such potential for economic and social progress," the report states. But the authors warn that this demographic surge could also have the potential to ISSN: 2332-6840 (Online) 2332-6832 (Print) Copyright (C) 2019 by authors, all rights reserved. Authors agree that this article remains permanently open access under the terms of the Creative Commons Attribution License 4.0 International License 
destabilize nations unless young people can secure access to health services, education and jobs.

The challenges are most acute for less developed countries, where nearly 9 out of 10 of the world's young people reside. India alone has a youth population of 356 million. The report's authors called on governments and donors to invest in this population's education, employment and health, particularly sexual and reproductive health. "International support can unlock the potential of the next generation of innovators, entrepreneurs, change agents and leaders," write the report's authors. These reports pin points towards the need of capacity building of young people.

\section{Global Scenario: Young World}

Young people's lives are more complex and challenging than ever, in most countries they are also more varied, full of opportunities and at same time a threat if not managed properly. In general, modern youth spend longer preparing for adulthood than their parents. However, the transition to adulthood is also laden with risks and challenges. According to Population Reference Bureau More than one in four persons in the world are youth and that share is expected to drop to 23 percent in 2025, largely because of declines in fertility (number of births per woman) in recent decades. In developing countries, youth are about 29 percent of the total population and are declining as a proportion of total population while still grow- ing in absolute numbers, altering the landscape for many social and financial policy issues. In sum, the number of youth will keep rising in some parts of the world, offsetting declines in other regions. There will be about 72 million more youth in 2025 than at present.

\section{Youth Population Ages 10-24, Tolal and as a Share of Population, 2006 and 2025}

\begin{tabular}{|c|c|c|c|c|}
\hline Region & $\begin{array}{l}\text { Number } \\
\text { in 2006 } \\
\text { (millions) }\end{array}$ & $\begin{array}{c}\text { Share } \\
\text { in } 2006 \\
\text { (\% of } \\
\text { pop.) }\end{array}$ & $\begin{array}{l}\text { Number } \\
\text { In 2025 } \\
\text { (millions) }\end{array}$ & $\begin{array}{l}\text { Share } \\
\text { in } 2025 \\
\text { (\% of } \\
\text { pop.) }\end{array}$ \\
\hline World & 1,773 & 27 & 1,845 & 23 \\
\hline Developed Regions & 236 & 19 & 207 & 17 \\
\hline Developing Regions & 1,537 & 29 & 1,638 & 25 \\
\hline Africa & 305 & 33 & 424 & 32 \\
\hline Asia & 1,087 & 28 & 1,063 & 22 \\
\hline North America & 71 & 21 & 74 & 19 \\
\hline Latin America/Caribbean & an 161 & 28 & 165 & 24 \\
\hline Europe & 140 & 19 & וו1 & 16 \\
\hline Oceania & 8 & 24 & 8 & 20 \\
\hline
\end{tabular}

source, L. Ashford, D. Clifton, and T. Kaneda, The World's Youth 2006 (Washington, DC: Population Reference Bureau, 2006).

Figure 1. Youth population across the globe 


\section{Young People and Life Skills}

Life skills help young people to steer away the challenges of everyday life. They enable them to develop into healthy, responsible, and productive adults. Adolescent life skills are central to psychological theories that aim to understand How skills and competencies develop. From a Practical standpoint, the promotion of life skills has been identified as a key resource for enabling positive and productive development in young people. The main definitions of life-skills, developed during the past decade, include similar basic abilities although using slightly different terminology and containing differences of emphasis.

Life skills-based education is now recognized as a methodology to address a variety of issues of child and youth development and thematic responses including as expressed in The UN General Assembly Special Session (UNGASS) on HIV/AIDS (2001), UNGASS on Children (2002), World Youth Report (2003), World Program for Human Rights Education (2004), UN Decade on Education for Sustainable Development (2005), UN Secretary General's Study on Violence Against Children (2006), 51st Commission on the Status of Women (2007), and the World Development Report (2007).

A 13-country study of life skills programs run by the International Youth Foundation (IYF) and Nokia demonstrates significant increases in young people's educational readiness, engagement in their communities, and their self-confidence and focus on the future. "Life are receiving considerable interest and support in this era of increasing globalization. The goal of life skills programs is to produce the kinds of citizens, workers, and parents that every society would like to see."

Although young people around the world are more and more likely to pursue formal education, upon graduation they often find that they are not adequately prepared for the world of work. Because skills relevant to key growth sectors of the modern economy - both technical and "soft" skills - are often not covered in traditional education systems, employers often find a "skills mismatch" between the competencies youth need to succeed in the workplace and those they actually possess. ${ }^{\mathrm{i}}$ This is a critical challenge for today's youth, and one key approach to overcoming this challenge is through the provision of life skills training.

\section{International Bodies and Life Skills}

World Health Organization has defined life skills as "abilities for adaptive and positive behavior that enable individuals to deal effectively with the demands and challenges of everyday life"

The ten core life skills laid down by WHO are:

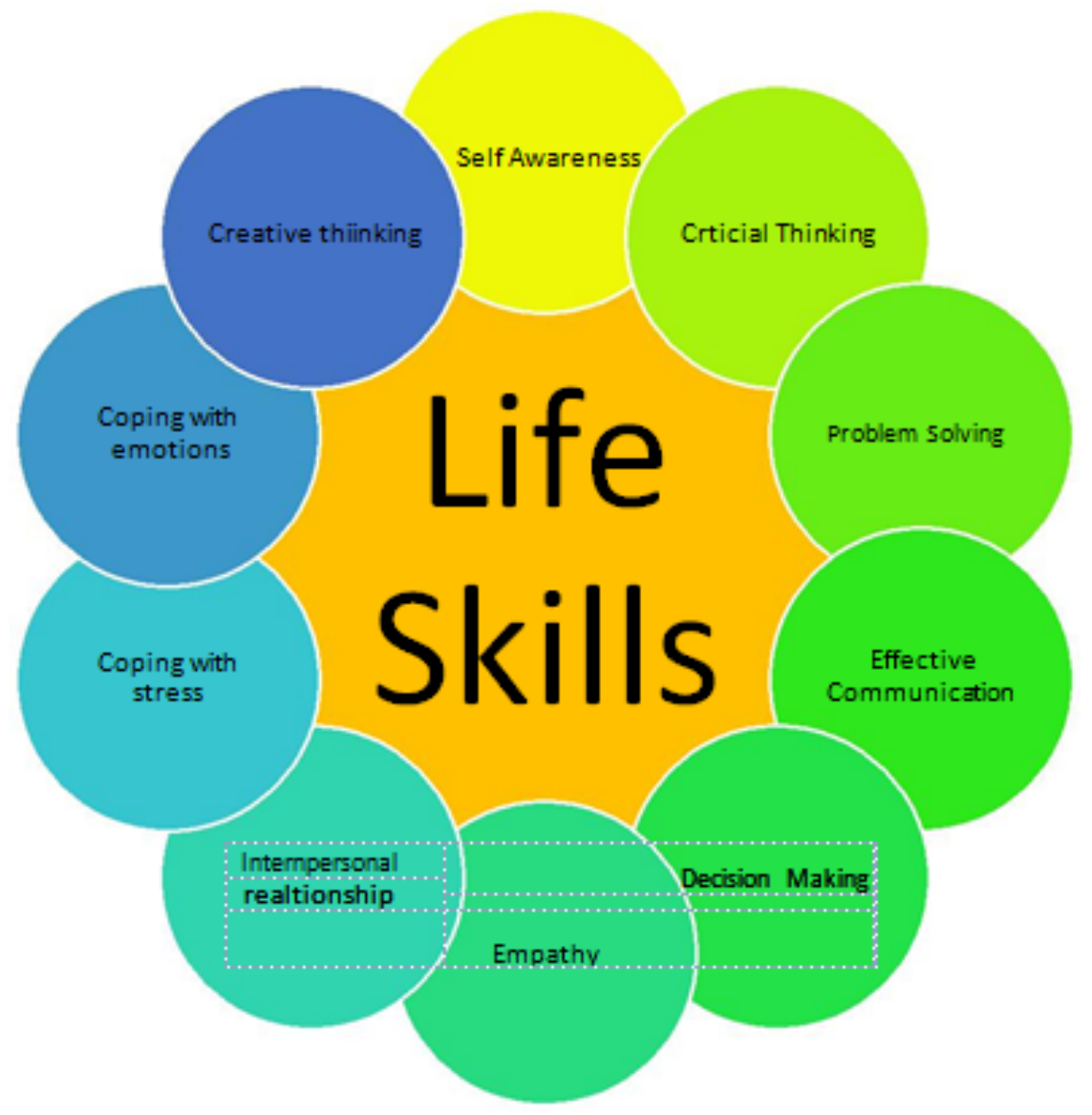

Figure2. World Health Organization defined 10 life skills 
There are plenty of other international bodies which defined and voices imparting life skill education among adolescent and young people in the community. Decision making and problem solving skills are very important for the survival of any individual in any sector. Communication and Interpersonal skills helps individuals to stay connected to each other. Creative thinking and critical thinking helps individuals to develop in their life.

Coping with emotions and stress can facilitate people to live their life at the fullest by being resilient and competent to the personal issues they face in the due course of their time.

WHOs life skills are a set of skill, which helps the social development professionals and organizations to impart the essential skills to the individuals.

Other international bodies define and prioritize life skills as follows;

Life Skills-Based Education (LSBE) has a long history of supporting child development and health promotion in many parts.

1. In 1986, the Ottawa Charter for Health Promotion recognized life skills in terms of making better health choices.

2. The 1989 Convention on the Rights of the Child (CRC) linked life skills to education by stating that education should be directed towards the development of the child's fullest potential.

3. The 1990 Jomtien Declaration on Education for All, took this vision further and included life skills among essential learning tools for survival, capacity development and quality of life.

4. The 2000 Dakar World Education Conference took a position that all young people and adults have the human right to benefit from "an education that includes learning to know, to do, to live together and to be", and included life skills in two out of the six EFA Goals.

5. Joint United Nations Programme on HIV/AIDS Department of Policy, Strategy and Research, Geneva. Advocates life skills education in schools for HIV/AIDS prevention and to promote care and empathy for HIV/AIDS sufferers.
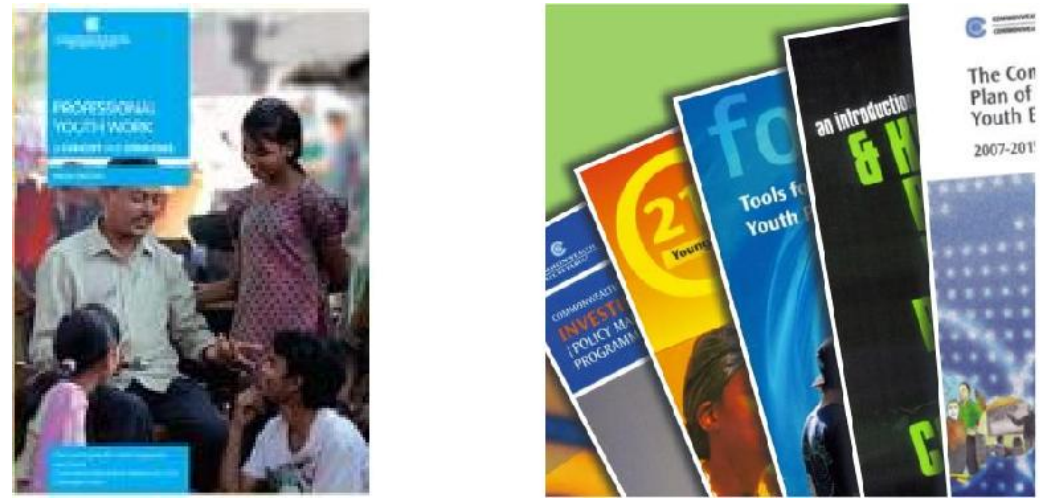

6. Office of the United Nations High Commissioner for Refugees (UNHCR): Promotes life skills learning in peace education programmes for conflict resolution and in AIDS education programmes for adolescents. Provides technical assistance and training to support field based development of such initiatives.

7. United Nations Children's Fund (UNICEF) New York (headquarters), Thailand, and Uganda: Advocates life skills education as a central element of programming for children and adolescents, for the promotion of health and development.

8. United Nations Population Fund (UNFPA) New York (headquarters) and West African Regional Office; Promotes life skills learning in population education curricula, with a focus on sexual and reproductive health. Provides training of trainers at the country level

There are several other international bodies, which do promotes life skill training among young people. Majority of them advocates for the mandatory inclusion of life skills in academia and vocational training across globe.

\section{Commonwealth and Young People}

The Commonwealth of Nations, or the Commonwealth, is an intergovernmental organization of 53 member states that were mostly territories of the former British Empire. The organization highlights the importance of young people in any society and thus has a special wing, which deals with Youth affairs. Commonwealth youth Programme is known for its continuing effort in making youth work as a profession in the member countries.

The Asia Regional Youth ministers meet held at New Delhi on July 27-30th has emphasized on youth participation and capacity building of young people in Asian countries like India, Pakistan, Bangladesh, Malaysia, Singapore, Maldives, Sri Lanka and Brunei Darussalam. The meeting has come up with a "Youth Declaration" Consisting 42 concerns raised by the youth leaders of the forum. Among which life skill training and capacity building of young people (inclusive) has been underlined.

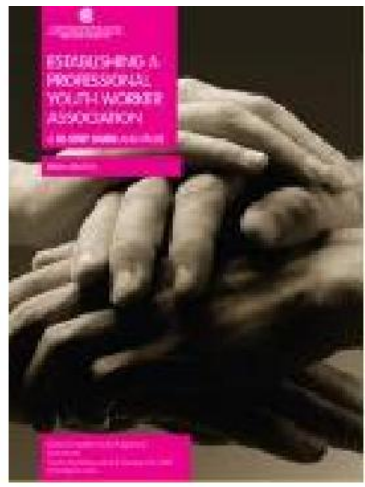

:http://www.youthdevelopmentindex.org/cms/cmsyouth/_images/18061685055239c0649590b.pdf

Figure 3. Catalogue of resource and publications of Commonwealth Secretariat 
Commonwealth identifies and envisioned as a group of expediters who recognize the positive and active role and contributions of young people in promoting development, peace, democracy and in protecting and promoting other Commonwealth values, such as tolerance and understanding, including respect for other cultures. The future success of the Commonwealth rests with the continued commitment and contributions of young people in promoting and sustaining the Commonwealth and its values and principles, and they commit to investing in and promoting young people's development, particularly through the creation of opportunities for youth employment and entrepreneurship. Commonwealth has come up with good number of training manuals, which can be openly accessed, widening the horizon of knowledge and sharing.

\section{A Model on Life Skills}

The Targeting Life Skills (TLS) Model is intended to be inclusive for all possible life skills. The terminology in the TLS Model is not the same as that used in any one other current list of life skills. By being generic, the model allows those developing curriculum to incorporate any specific life skill that youth programmers may wish to address using whichever terminology is descriptive of that skill.

The purpose of the TLS Model is to provide a way to simplify coordination of life skill development with ages and stages tasks so programs will be developmentally appropriate and more effective in achieving identified outcomes. For too long these strategies have been treated separately when describing aspects of youth development. Life skill development is mapped sequentially over four age groupings of youth to indicate a continuum of growth. This continuum will guide planners in identifying an appropriate developmental level for content delivery. By assigning developmentally appropriate tasks to specific life skills, the TLS Model has the potential to greatly improve the possibility of achieving measurable program success in youth development. There is not complete agreement on the specific life skills needed by youth, or on a set of desired behaviors that ensure success in life. It is easier to identify the problem behaviors that occur when the youth do not reach the expected societal goals.

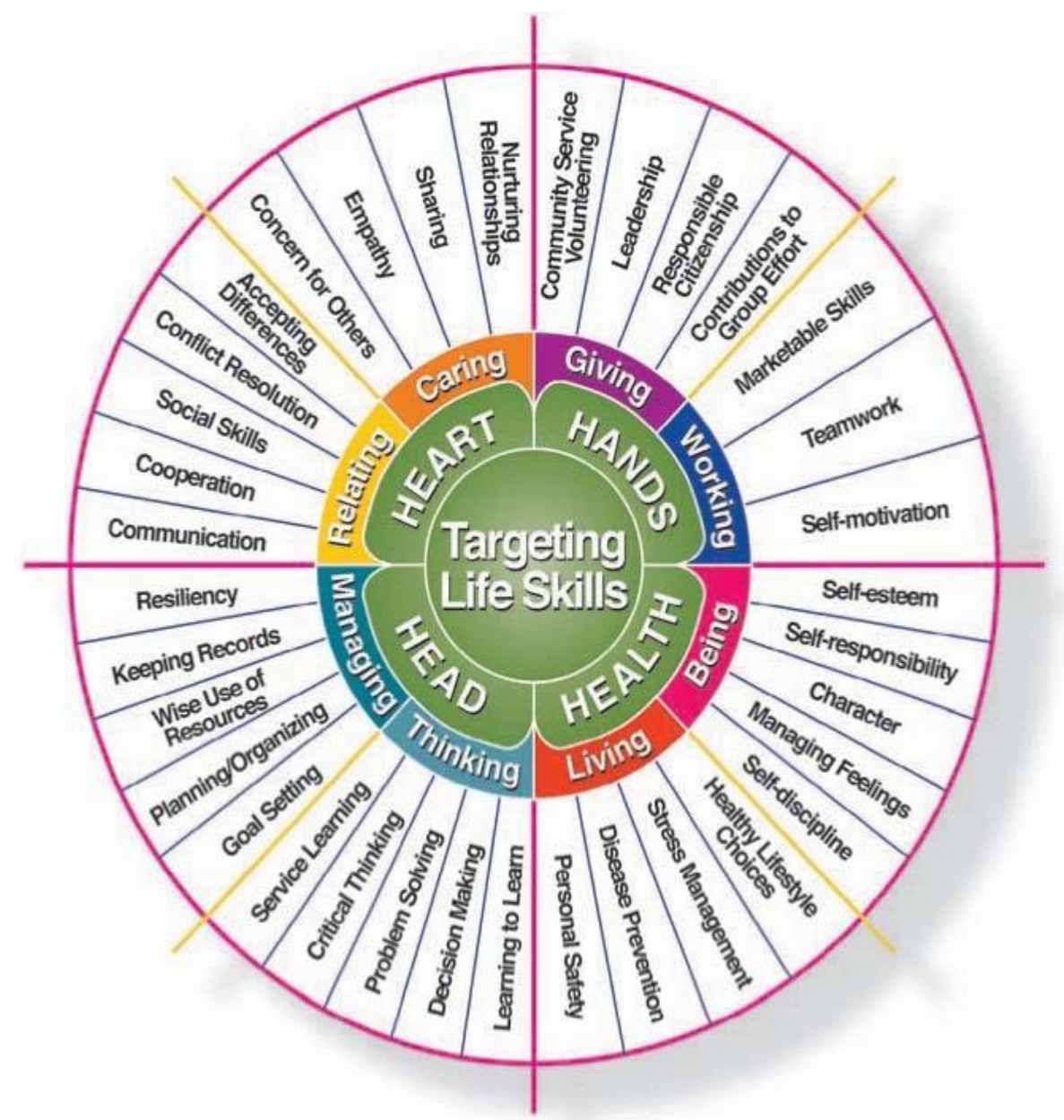

Targeting Life Skills model. Source: Hendricks 1996.

Figure 4. Targeting Life-skills Model 


\section{Need for Convergence}

By reviewing a number of models proposed by several authors, certain consistent categories of competencies emerged. These categories can be used as the basis of life skill development. Authors generally agree that life skills are learned through experience. Life skills often must be practiced over and over before mastery is achieved.

There has been a huge pool of resources around us, particularly for Life skill training which has been conceptualized and drafted by international bodies through expert consultancies and pilot studies. It is equally important that the trainers who are imparting life skills among the young people must go through these resource and update self before venturing into training. Singapore and Malaysia have comparatively better 'style' while dealing with young people. Countries like

India, Bangladesh and Pakistan can look into such models and will be effective if replicated accordingly. Intensive research must be carried out in order to capture the effectiveness of life skill training. Experimental research must be encouraged. Countries like India where more than 60 percentage of the population constitutes young people must seriously look into youth research with special focus on developing effective models which can address the different sections of young people in the nation.

\section{Way Forward}

As the international youth workers rightly point outs young men and women are not passive beneficiaries, but equal and effective partners. Their aspirations extend far beyond jobs; youth also want a seat at the table: a real voice in shaping the policies that shape their lives. We need to listen to and engage with young people. We need to establish more and stronger mechanisms for youth participation. And for effective participation the policy makers must ensure a conducive environment where the young people are nurtured well. Around the world, there is growing recognition of the need to strengthen policies and investments involving young people. Youth can determine whether this era moves toward greater peril or more positive change. All the organizations and institutes must support the young people so they grow into adults who rise yet more generations of productive and powerful leaders.

There must be a convergence of models in terms of giving importance to the reflective and experiential learning. The idea of providing space and freedom to young people is essential in the any such models. The TLS model. Commonwealth model and the WHOs description of life skill training clearly states the importance of customized and 'need sensed' training programmes for the young people involved and it further illustrates the importance of working "with " young people than working "for" young people

\section{REFERENCES}

[1] Nugent, R. (n.d.). Youth in Global World. Retrieved August 17, 2015, from http://www.prb.org/pdf06/YouthInAGlobal World.pdf

[2] Population Reference Bureau 1875 Connecticut Ave., NW, Suite 520, Washington, DC 20009 USA

[3] Time magazine : Retrieved From http://time.com/3591947/ young-people-united-nations/ on 8th August 2014

[4] WHO (1999), Partners in Life Skills Training: Conclusions from a United Nations Inter-Agency Meeting, Geneva

[5] WHO (2004), Skills for health: An important entry-point for health promoting/child-friendly schools, Geneva.

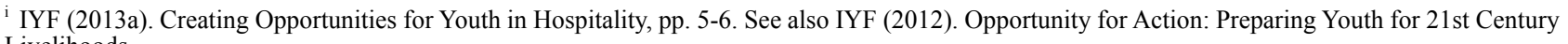
Livelihoods 